\title{
STUDI EKSPERIMEN PENGOLAHAN BROWNIES KUKUS BERBAHAN BAKU TEPUNG UBI JALAR UNGU
}

\author{
Irham Sani, Cokorda Istri Raka Marsiti, Luh Masdarini \\ Jurusan Pendidikan Kesejahtraan Keluarga \\ Universitas Pendidikan Ganesha \\ Singaraja, Indonesia \\ e-mail:irhamsani999@gmail.com, raka.marsiti@undiksha.ac.id, \\ masdarini@undiksha.ac.id
}

\begin{abstract}
Abstrak
Penelitian eksperimen ini bertujuan untuk mengetahui (1) kualitas brownies kukus tepung ubi jalar ungu dengan bahan $100 \%$ tepung ubi jalar ungu dilihat dari aspek tekstur dan rasa. Metode pengumpulan data yang digunakan dalam penelitian ini yaitu metode observasi dengan menggunakan instrumen berupa lembar uji organoleptik dengan 3 tingkatan yaitu baik, cukup, kurang. Panelis dalam penelitian ini merupakan panelis terlatih yang terdiri dari 25 orang panelis. Teknik analisis data yang digunakan teknik deskriptif kuantitatif. Hasil penelitian menunjukan (1) kualitas brownies kukus tepung ubi jalar ungu dilihat dari aspek tekstur berada dalam kategori baik dengan skor $(2,80)$ yaitu memiliki tekstur lembut dan berpori, kualitas brownies kukus tepung ubi jalar ungu dilihat dari aspek rasa berada dalam kategori baik dengan skor $(2,68)$ yaitu memiliki rasa manis dan khas ubi jalar ungu.
\end{abstract}

Kata kunci : brownies kukus, kualitas, tepung ubi jalar ungu

\begin{abstract}
Experimental research is aimed to know (1) quality of brownies steamed purple sweet potato flour with materials $100 \%$ purple sweet potato flour seen from the aspect texture and taste. Method of collecting data used in this research that is method observation with use instrument in the form of sheets test organoleptic with 3 levels that is good, enough, lees. Panelists inside this research is a panelist trained which consist of 25 person panelist. Analytical techniques data used technique descriptive quantitative. Research result show (1) quality of brownies steamed purple sweet potato flour seen from the aspect texture located in good category with score $(2,80)$ that is have texture soft and porous, quality of brownies steamed purple sweet potatoflour seen from taste located in good category with score $(2,68)$ that is have taste sweet and typical purple sweet potato.
\end{abstract}

Keywords : steamed brownies, quality, purple sweet potato flour

\section{PENDAHULUAN}

Umbi-umbian merupakan sumber karbohidrat alternatif yang berasal dari sumber daya lokal. Umbi-umbian adalah segala jenis tanaman yang menghasilkan umbi. Tanaman umbi-umbian dapat tumbuh baik di daerah yang kesuburan tanahnya kurang baik dan pengairannya kurang bagus. Dilihat dari kandungan gizi dan kemudahan budi dayanya, umbi-umbian patut dikembangkan serta diawetkan dalam bentuk tepung dan pati (Murtiningsih \& Suyanti, 2001:107).

Umbi-umbian mempunyai potensi untuk dikembangkan sebagai bahan pangan pengganti beras (bahan baku industri pangan maupun non pangan ). Tanaman umbi-umbian umumnya ditanam di lahan semi kering sebagai tanaman sela. 
Jurnal Bosaparis: Pendidikan Kesejahteraan Keluarga

Volume 9, Nomor 1, Maret 2018

Berdasarkan data statistik tingkat produksi ubi jalar di Kabupaten Buleleng pada tahun 2011 s/d 2015 yaitu produksi ubi jalar pada tahun 2011 mencapai 433 ton dengan areal panen (ha) seluas 36, tahun 2012 mencapai 222 ton dengan areal panen 20 (ha), tahun 2013 mencapai 286 ton dengan areal panen 19 (ha), tahun 2014 mencapai 115 (ton) dengan areal panen 14 (ha), tahun 2015 mencapai 101 (ton) dengan areal panen 7 (ha). (Suastini.2015)

Selama ini ubi jalar kurang atau belum banyak dimanfaatkan untuk dijadikan suatu produk makanan tambahan, harga ubi jalar terjangkau, ubi jalar mudah didapat dan tidak mengenal musim. Ubi jalar pada umumnya dibuat kripik, direbus, dikukus atau digoreng saja untuk dimakan. Padahal di dalam ubi jalar terkandung zat gizi yang sangat bermanfaat bagi tubuh yaitu kandungan serat yang tinggi sehingga cukup baik bagi pencernaan. Kelemahan ubi jalar adalah cepat busuk jika dalam keadaan segar, (Sarwono.2005.67).

Tepung ubi jalar ungu adalah tepung yang terbuat dari ubi jalar ungu secara langsung dengan cara dikeringkan kemudian diperoleh dari hasil penumbukan atau penggilingan setelah itu diayak sehingga menghasilkan jenis tepung yang halus.Untuk menghindari tepung mudah rusak, begitu selesai penggilingan tepung ubi jalar harus segera dikemas dalam kantong plastik dan segera ditutup rapat, karena tepung ubi jalar juga bersifat higroskofis, yaitu mudah menyerap air dari udara sehingga mudah rusak dan asam. (Suprapti. 2007).

Tabel 01:

Kandungan Gizi Tepung Ubi Jalar Ungu Dan Tepung Terigu Per 100 Gr

\begin{tabular}{lcl}
\hline Komponen & $\begin{array}{c}\text { Tepung Ubi Jalar } \\
\text { Ungu }\end{array}$ & Tepung Terigu \\
\hline Air & 7,28 & 11,8 \\
Protein & 2,79 & 9,0 \\
Lemak & 0,81 & 1,0 \\
Karbohidrat & 83,81 & 77,2 \\
Abu & 5,31 & 0 \\
Serat & 4,72 & 0 \\
\hline
\end{tabular}

Sumber : Ambarsari,dkk,2000 dan komposisi pangan indonesia (2009)

Kandungan karbohidrat dari tepung ubi jalar ungu tidak jauh berbeda dengan kandungan karbohidrat pada tepung terigu sehingga dapat digunakan sebagai bahan pembuatan kue. Melihat tabel di atas kandungan gizi tepung ubi ungu dan kandungan gizi tepung terigu tidak jauh berbeda sehingga dapat digunakan dalam pembuatan aneka makanan berupa bolu, brownies dll.

Berdasarkan tabel 1.1 di atas, tepung ubi jalar ungu memiliki kandungan karbohidrat sebesar $83,81 \%$, air 7,28\%, abu $5,31 \%$, protein $2,79 \%$, lemak $0,81 \%$, dan serat $4,72 \%$. Dilihat dari karakteristik tepung ubi jalar ungu memiliki tekstur yang halus dengan warna ungu sesuai dengan ubi jalar ungu yang dipakai, mempunyai aroma khas tepung ubi jalar pada umumnya. Di masyarakat produk olahan dari tepung ubi jalar masih terbatas karena tepung ubi jalar ungu belum dimanfaatkan secara maksimal oleh masyarakat. Padahal tepung ubi jalar ungu dengan 
Jurnal Bosaparis: Pendidikan Kesejahteraan Keluarga

Volume 9, Nomor 1, Maret 2018

tepung terigu tidaklah jauh berbeda bila dilihat dari segi kandungan karbohidratnya. Dengan adanya tepung ubi jalar ungu dapat mengurangi penggunaan tepung terigu oleh masyarakat karena tepung ubi jalar ungu adalah salah satu jenis tepung yang berasal dari bahan lokal. Dengan adanya pemanfaatan tepung ubi jalar ungu dalam pembuatan suatu produk pangan dapat menambah nilai gizi dan dapat meningkatkan mutu produk pangan, seperti produk brownies kukus.

Brownies merupakan salah satu jenis cake yang berwarna cokelat kehitaman dengan tekstur sedikit lebih keras dari pada cake karena brownies tidak membutuhkan pengembang atau gluten (Astawan 2009:51). Penggunaan tepung ubi ungu diharapkan dapat meningkatkan diversivikasi olahan makanan berbahan dasar tepung ubi ungu. Brownies dapat dikategorikan menjadi dua yaitu brownies panggang dan brownies kukus. Perbedaanya hanya terletak pada kandungan kadar air didalamnya. Brownies panggang memiliki kadar air yang lebih rendah, sehingga memiliki daya simpan yang tinggi.

Dalam penelitian ini, peneliti bertujuan untuk membuat produk brownies kukus dengan bahan $100 \%$ tepung ubi jalar ungu dimana hasil eksperimen diuji dengan lembar uji kualitas yang dilakukan oleh beberapa panelis untuk menguji kualitas brownies kukus dari tepung ubi jalar ungu yang dilihat dari aspek tekstur dan rasa

\section{METODE}

Jenis penelitian yang dilakukan adalah penelitian eksperimen. Penelitian eksperimen yang bertujuan untuk meneliti suatu objek dengan melakukan suatu percobaan secara nyata di lapangan (Arikunto, 2006). Di dalam penelitian yang akan diteliti yaitu studi eksperimen pengolahan brownies kukus berbahan baku tepung ubi jalar ungu, pertama peneliti akan menggolah ubi jalar ungu menjadi tepung, setelah ubi jalar ungu menjadi tepung akan digunakan sebagai bahan utama dalam membuat brownies kukus dengan menggunakan resep dasar brownies kukus. Kemudian akan diuji kualitas dilihat dari aspek tekstur dan rasa. mengisi lembar uji kualitas atau lembar observasi, dari pengisian lembar uji kualitas maka akan diperoleh data dan kemudian akan dianalisis sehingga mendapatkan kesimpulan.

Selanjutnya dari uji kualitas tersebut akan memperoleh data yang dianalisis dan memperoleh kesimpulan akhir. Dalam penelitian eksperimen menggunakan uji organoleptik.Uji organoleptik adalah pengujian yang dilakukan dengan menggunakan organ indera manusia sebagai instrumen / alat uji. Penilaian yang digunakan pada brownies kukus adalah mengacu pada penilaian dari aspek tekstur dan rasa tidak menggunakan penilaian aroma dan warna karena dari segi aroma lebih khas aroma cokelat dibandingkan khas aroma ubi jalar ungu dan dari segi aspek warna sudah berwarna cokelat sehingga tidak menggambil penilaian warna.

Jenis uji organoleptik dalam penelitian ini menggunakan uji mutu hedonik. Uji mutu hedonik merupakan pernyataan kesan tentang baik buruknya suatu produk makanan (Soekarto, 1985). Panelis yang dipilih dalam penelitian ini adalah panelis terlatih, panelis terlatih ini berfungsi sebagai alat analisis, dan pengujian yang dilakukkan biasanya terbatas pada kemampuan membedakan.Panelis ini terdiri dari 15 - 25 orang yang mempunyai kepekaan cukup baik. Dalam penelitian ini mengunakan uji panelis terlatih yaitu 25 orang. Yang merupakan panelis dalam penelitian ini yaitu 2 orang Dosen PKK Tata Boga, 11 orang Guru SMK Negeri 2 Singaraja, 4 orang Guru SMK Triatmajaya Singaraja, dan 8 orang Guru SMK Negeri 1 Seririt.

Dalam pengumpulan data digunakan alat berupa lembar observasi uji kualitas. 
Jurnal Bosaparis: Pendidikan Kesejahteraan Keluarga

Volume 9, Nomor 1, Maret 2018

Panelis menanggapi dengan cara memberikan tanda check list $(\sqrt{ })$ sesuai dengan kriteria yang sudah ditentukan pada lembar observasi panelis terhadap kualitas brownies kukus tepung ubi jalar ungu.. Instrumen yang digunakan dalam penelitian ini berupa lembar observasi uji kualitas brownies kukus tepung ubi jalar ungu yang diberikan kepada setiap panelis untuk menilai kualitas produk yang akan disediakan. Pada mutu hedonik, data penilaian dapat ditrasformasikan dalam skala numerik dan selanjutnya dapat dianalisis statistik untuk interpretasinya (Soekarto, 1985:81).Tolok ukur dalam lembar uji kualitas digunakan untuk mendapatkan hasil dari responden. Dalam penelitian ini digunakan skala mutu hedonik dengan 3 rentangan skala, yaitu:

Tabel 02.

Skala Mutu Hedonik dan Skala Numerik

\begin{tabular}{cc}
\hline Skala Mutu Hedonik & Skala Numberik \\
\hline Baik & 3 \\
Cukup & 2 \\
Kurang & 1 \\
\hline
\end{tabular}

Tabel 03.

Lembar Uji Kualitas Brownies Kukus Tepung Ubi Jalar Ungu Dari Aspek Rasa dan Tekstur

\begin{tabular}{|l|l|c|c|c|}
\hline \multirow{2}{*}{ No } & \multirow{2}{*}{ Aspek Penilaian } & \multicolumn{3}{|c|}{ Brownies kukus tepung ubi jalar ungu } \\
\cline { 3 - 5 } & & 3 & 2 & 1 \\
\hline 1 & Rasa & & & \\
\hline 2 & Tekstur & & & \\
\hline
\end{tabular}

Tabel 04.

Tolok Ukur Uji Kualitas Brownies Kukus Tepung Ubi Jalar Ungu Dari Aspek Rasa dan Tekstur

\begin{tabular}{|c|l|l|}
\hline Nilai & \multicolumn{1}{|c|}{ Rasa } & \multicolumn{1}{c|}{ Tekstur } \\
\hline 3 & $\begin{array}{l}\text { Manis dan khas ubi jalar } \\
\text { ungu }\end{array}$ & Lembut dan berpori \\
\hline 2 & $\begin{array}{l}\text { Tidak manis dan khas ubi } \\
\text { jalar ungu }\end{array}$ & $\begin{array}{l}\text { Salah satu kriteria } \\
\text { terpenuhi }\end{array}$ \\
\hline 1 & $\begin{array}{l}\text { Tidak manis dan tidak khas } \\
\text { ubi jalar ungu }\end{array}$ & $\begin{array}{l}\text { Semua kriteria tidak } \\
\text { terpenuhi }\end{array}$ \\
\hline
\end{tabular}


Penelitian ini yang akan dicapai adalah mengetahui kualitas brownies kukus dilihat dari aspek tekstur dan rasa. Sesuai dengan tujuan penelitian ini menggunakan metode analisis deskriptif kuantitatif. Analisis deskriptif kuantitatif adalah suatu cara pengolahan data dengan cara menyusun secara sistematis dalam bentuk angka-angka mengenai objek yang akan diteliti untuk mendapatkan kesimpulan akhir

\section{Keterangan:}

$\mathrm{M}=$ Mean (rata-rata)

$\sum x=$ Jumlah masing-masing skor

$N=$ Jumlah panelis

Sumber: Koyan (2011:112)

Acuan persentase pengambilan keputusan yang digunakan untuk menentukan kualitas brownies kukus tepung ubi jalar ungu dilihat dari aspek tekstur dan rasa. Rumus pedoman konversi skala 3 (tiga) adalah sebagai berikut:

\begin{tabular}{|l|}
\hline$M+1 S D \rightarrow M+3 S D$ \\
\hline$M-1 S D \rightarrow M+1 S D$ \\
\hline$M-3 S D \rightarrow M-1 S D$ \\
\hline
\end{tabular}

Keterangan rumus:

$\mathrm{M} \quad=$ Mean (rata tengah)

SD = Standar deviasi (Koyan, 2011:122)

Keterangan:

Skor maksimum $=3$

Skor minimum $\quad=1$
Setelah melakukan analisis data dengan metode deskriptif kuantitatif diperoleh kesimpulan pada kualitas brownies kukus tepung ubi jalar ungu dilihat dari aspek tekstur dan rasa. Adapun rumus yang digunakan yaitu:

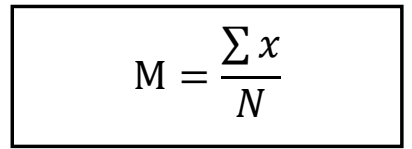

$M=$ Mean atau rata-rata yang dicari dengan rumus:

$\mathrm{M}=\frac{1}{2} \times($ Skor Maksimun + Skor Minimum $)$

$\mathrm{SD}=$ Standar Deviasi yang dicari dengan rumus:

$\mathrm{SD}=\frac{1}{6} \times($ Skor Maksimun + Skor Minimum $)$

Berdasarkan rumus diatas maka data yang sudah terkumpul akan dicari konversinya sehingga mendapatkan hasil sebagai berikut:

$\mathrm{M}=\frac{1}{2} \times($ Skor Maksimun + Skor Minimum $)$

$\mathrm{M}=\frac{1}{2} \times(3+1)$

$M=2$

$\mathrm{SD}=\frac{1}{6} \times($ Skor Maksimun - Skor Minimum $)$

$\mathrm{SD}=\frac{1}{6} \times(3-1)$

$\mathrm{SD}=0,33$

Acuan pengambilan keputusan yang digunakan untuk mentukan kualitas brownies kukus dilihat dari aspek tekstur dan rasa berdasarkan rumus pedoman konversi dengan skala 3 (tiga) adalah sebagai berikut: 
Jurnal Bosaparis: Pendidikan Kesejahteraan Keluarga

Volume 9, Nomor 1, Maret 2018

$$
\begin{aligned}
& 2,33-3,00=\text { Baik } \\
& 1,67-2,32=\text { Cukup } \\
& 1,00-1,66=\text { Kurang }
\end{aligned}
$$


Jurnal Bosaparis: Pendidikan Kesejahteraan Keluarga

Volume 9, Nomor 1, Maret 2018

\section{HASIL DAN PEMBAHASAN}

Penelitian ini dilaksanakan di laboratorium Produksi Tata Boga Jurusan Pendidikan Kesejahteraan Keluarga dan pengumpulan data dari aspek tekstur dan rasa dilaksanakan pada tanggal $3-8$ Maret 2018. Dalam penelitian ini menggunakan panelis terlatih yaitu 25 panelis yang terdiri dari 2 orang Dosen Pkk Tata Boga, 11 orang guru Tata Boga di SMK Negeri 2 Singaraja, 8 orang guru Tata Boga di SMK Negeri 1 Seririt, 4 orang Guru Tata Boga di
SMK Triatma Jaya Singaraja. Kualitas brownies kukus tepung ubi jalar ungu dilihat dari aspek tekstur dan rasa. Proses pengolahan brownies kukus tepung ubi jalar ungu dengan menggunakan resep baku brownies kukus tepung terigu. Dilaksanakan pada tanggal 15 Juli 2017. Brownies kukus tepung ubi jalar ungu dibuat dengan menggunakan bahan tepung ubi jalar ungu $100 \%$ hasilnya sudah sesuai dengan kriteria brownies kukus pada umumnya.

Tabel 05.

Rekapitulasi Data Hasil Penelitian Brownies Kukus Tepung Ubi Jalar Ungu

\begin{tabular}{|c|c|c|c|c|c|c|}
\hline \multirow{2}{*}{$\begin{array}{l}\text { Aspek } \\
\text { Dinilai }\end{array}$} & \multirow[t]{2}{*}{ Yang } & \multicolumn{5}{|c|}{ Brownies kukus tepung ubi jalar ungu } \\
\hline & & $\sum x$ & $\begin{array}{l}\text { Jumlah } \\
\text { Sampel (N) }\end{array}$ & $\begin{array}{l}\text { Rata- } \\
\text { (Mean) }\end{array}$ & Rata & Kategori \\
\hline $\begin{array}{l}\text { Rasa } \\
\text { Tekstur }\end{array}$ & & $\begin{array}{l}67 \\
70\end{array}$ & $\begin{array}{l}25 \\
25\end{array}$ & $\begin{array}{l}2,68 \\
2,80\end{array}$ & & $\begin{array}{l}\text { Baik } \\
\text { Baik }\end{array}$ \\
\hline
\end{tabular}

Berdasarkan Tabel 05 diperoleh hasil uji panelis brownies kukus tepung ubi jalar ungu dilihat dari aspek tekstur brownies kukus tepung ubi jalar ungu memperoleh skor 2,80 berada pada kategori baik sesuai dengan tolok ukur yaitu lembut dan berpori. Sedangkan berdasarkan hasil uji kualitas brownies kukus tepung ubi jalar ungu dilihat dari aspek rasa memperoleh skor 2,68 berada pada kategori baik yaitu manis dan khas ubi jalar ungu. Berdasarkan hasil uji kualitas brownies kukus tepung ubi jalar ungu yang dilihat dari aspek tekstur dan rasa dapat dilihat pada diagram batang dibawah ini:

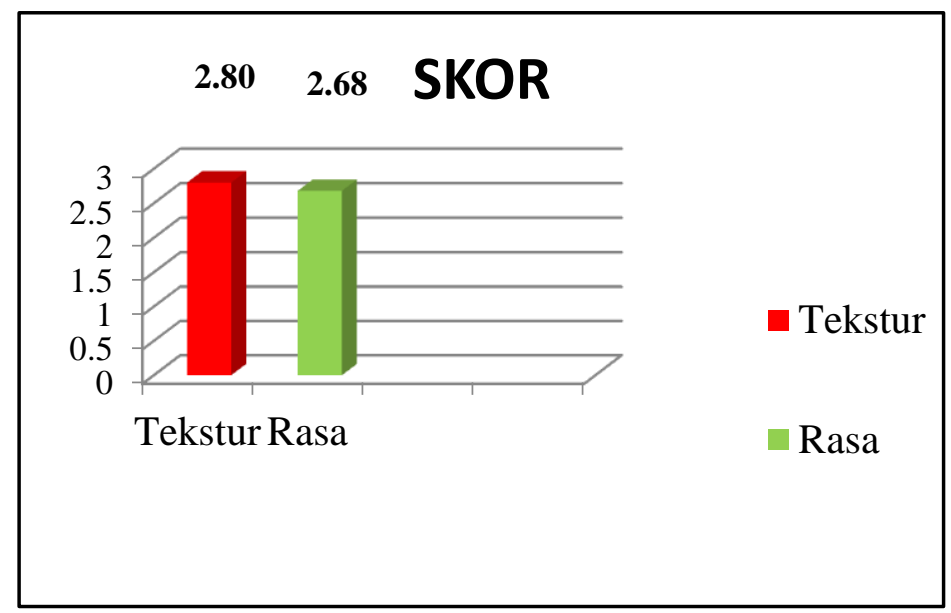


Dari hasil uji panelis yang dilakukan, diketahui bahwa brownies kukus tepung ubi jalar ungu dilihat dari aspek rasa memperoleh skor rata-rata 2,68 masuk dalam kategori baik sesuai dengan kriteria manis dan khas ubi jalar ungu. Sehingga kualitas brownies kukus tepung ubi jalar ungu berada pada kategori baik sesuai dengan tolok ukur yang telah ditentukan yaitu manis dan khas ubi jalar ungu. Rasa manis diperoleh dari ubi jalar ungu dan perpaduan antara cokelat bubuk, cokelat batang dan gula. Oleh karena itu, kriteria brownies kukus secara umum dari segi rasa adalah memiliki rasa manis. Hal ini di dukung oleh teori menurut (Ismayani $\mathrm{Y}$, 2006) yang menyatakan bahwa ciri khas brownies kukus adalah rasanya manis.

Berdasarkan dari hasil uji panelis yang dilakukan, diketahui bahwa brownies kukus tepung ubi jalar ungu dilihat dari aspek tekstur memperoleh skor rata-rata 2,80. Tekstur dari brownies kukus tepung ubi jalar ungu memiliki tekstur lembut dan berpori.Sehingga kualitas brownies kukus tepung ubi jalar ungu berada pada kategori baik sesuai dengan tolok ukur yang telah ditentukan yaitu lembut dan berpori. Hal ini di dukung oleh teori menurut (Ismayani $\mathrm{Y}$, 2006) yang menyatakan bahwa ciri khas brownies kukus adalah teksturnya lembut dan berpori. Brownies kukus tepung ubi jalar ungu memiliki tekstur lembut dan berpori sesuai dengan kriteria brownies kukus tepung terigu pada umumnya.

\section{RANGKUMAN, SIMPULAN DAN SARAN}

\section{Rangkuman}

Ubi jalar ungu (Ipomoea batatas var Ayumurasaky) biasa disebut Ipomoea Batatas karena memiliki kulit dan daging umbi yang berwarna ungu kehitaman (ungu pekat). Ubi jalar ungu mengandung pigmen antosianin yang lebih tinggi dari pada ubi jalar jenis lain. (Sri Kumalaningsih.2006:81). Pigmen warna ungu pada ubi jalar ungu bermanfaat sebagai antioksidan karena dapat menyerap polusi udara, racun, oksidasi dalam tubuh, dan menghambat pengumpulan sel-sel darah.

Pengumpulan data untuk penelitian ini dilaksanakan di Jurusan Pendidikan Kesejahteraan Keluarga (Tata Boga), SMK N 2 Singaraja, SMK Pariwisata Triatma Jaya dan SMK Negeri 1 Seririt pada tanggal 3-8 Maret 2018. Hasil yang didapat dari uji kualitas brownies kukus tepung ubi jalar ungu yang telah dilakukan terhadap 25 orang panelis terlatih yaitu dari aspek tekstur berada pada kategori baik dan memperoleh skor rata-rata 2,80 sesuai dengan tolok ukur yaitu tekstur lembut dan berpori. Kualitas brownies kukus tepung ubi jalar ungu dari aspek rasa memperoleh skor rata-rata 2,68 dan berada pada kategori baik sesuai dengan tolok ukur yaitu memiliki rasa manis dan khas ubi jalar ungu.

\section{Simpulan}

Berdasarkan hasil uji kualitas brownies kukus tepung ubi jalar ungu yang telah dilakukan terhadap 25 orang panelis terlatih, maka dapat disimpulkan hasil uji kualitas brownies kukus tepung ubi jalar ungu dari aspek tekstur berada pada kategori baik dan memperoleh skor ratarata 2,80 sesuai dengan tolok ukur yaitu memiliki tekstur lembut dan berpori. Kualitas brownies kukus tepung ubi jalar ungu dari aspek rasa memperoleh skor rata-rata 2,68 dan berada pada kategori baik sesuai dengan tolok ukur yaitu memiliki rasa manis dan khas ubi jalar ungu.

\section{Saran}

Kepada peneliti selanjutnya dapat menggembangkan inovasi prodak baru seperti kue kering dan cake dari tepung ubi jalar ungu agar memiliki nilai jual tinggi, dan diharapkan kepada masyarakat daerah yang memiliki ubi jalar ungu diharapkan dapat memanfaatkan ubi jalar ungu sebagai produk olahan sehingga dapat meningkatkan nilai ekonomi dari ubi jalar ungu. 
Jurnal Bosaparis: Pendidikan Kesejahteraan Keluarga

Volume 9, Nomor 1, Maret 2018

\section{DAFTAR PUSTAKA}

Arikunto, Suharsimi. 2006. Prosedur Penelitian Suatu Pendekatan Praktek, Edisi Revisi VI. Jakarta : PT Reineka Cipta

Astawan.2005. Ahli Teknologi Pangan dan Gizi. Institude Pertanian Bogor IPB.

Ambarsari.2000. Komposisi Pangan Indonesia.2009. Jenis Zat Gizi Tepung Ubi Jalar Ungu dan Tepung Terigu.

Ismayani.2006. Pengertian Brownies

Koyan, I Wayan. 2011. Asesmen Dalam Pendidikan. Singaraja: Universitas Pendidikan Ganesha.

Murtiningsih, dan Suyanti.2001. Tepung Ubi Jalar.

Sri Kumalaningsih.2006. Ubi Jalar Ungu dan Proses pengolahannya.

Suastini.2015. Data Statistik Tingkat Produksi Ubi Jalar di Kabupaten Buleleng Pada Tahun 2011-2015.

Suprapti.2007.Tepung Ubi Jalar Ungu Pembuatan dan Pemanfaatanya. Yogyakarta : Kanisius. 